\title{
Complaints Information System for the Polytechnic of South
} Aceh

\author{
M Arinal Ihsan ${ }^{\text {a., }, ~}{ }^{*}$, Hasbaini ${ }^{\text {b,2., }}$, Fardiansyah ${ }^{\text {c,3. }}$, DS Putra ${ }^{\text {d,4. }}$, Asmaidi ${ }^{\text {e,5. }}$ \\ a,b,c,d,e Polytechnic of South Aceh, Merdeka Street, Komplek Reklamasi Pantai, Tapaktuan city, 23751, Indonesia \\ l*m.arynalihsan@gmail.com
}

ARTICLE INFO

Article history:

Accepted

Keywords:

Information System

Complaint System

Stakeholder

SPMI

\section{ABSTRACT}

The industrial revolution 4.0 is a hot topic discussed only among academics and industry. Of course, this condition is a positive thing that shows that people have started to care about utilizing technology that is developing very rapidly today. South Aceh Polytechnic (POLTAS) as a vocational higher education institution, of course, must be consistent in making innovations in improving services to stakeholders. The quality and quality of service to stakeholders must of course be maintained so that input, criticism, and suggestions from them are one of the most important factors in creating a safe and comfortable academic atmosphere for higher education, especially POLTAS. The formulation of the problem in this study is how to build and simulate the results of an information system that can adapt dynamically in carrying out the political services of South Aceh provided to stakeholders. The purpose of this research is to build a Complaints Information System for the Polytechnic of South Aceh (SIAPA). This research is also part of the POLTAS Internal Quality Assurance System (SPMI) which is managed independently assigns to control and improve quality in the implementation of higher education in a planned manner (with designed) and sustainable (sustainable). This type of research is applied research with case studies at the South Aceh Polytechnic. The research procedure is in several stages, namely planning, analysis, design, development, testing, implementation, simulation of results, and evaluation.

Copyright (C) 2021 Politeknik Aceh Selatan. All rights reserved.

\section{Introduction}

South Aceh Polytechnic (POLTAS) as an institution that provides vocational higher education must be consistent in making innovations in improving services to stakeholders. Quality services to stakeholders must be maintained so that complaints and suggestions from them can be an important factor in creating a conduciveacademic atmosphere in higher education institutions, especially POLTAS. Previous input, criticism, and suggestions were only made during monthly meetings or inactivity evaluation meetings. Usually, with a long pause, these criticisms and suggestions will have an impact on the freedom to express ideas and innovations in the process of improving the service quality.The formulation of the problem in this study is how to build and simulate information system products that can adapt dynamically in assessing the services of the South Aceh Polytechnic provided to stakeholders. This research is also part of the POLTAS Internal Quality Assurance System (SPMI) which is managed independently to control and improve quality in the implementation of higher education by design and sustainability.

The purpose of this research is to develop the South Aceh Polytechnic Complaints Information System (SIAPA), which provides basic information and references in making policies for POLTAS leaders. This type of research is applied research with case studies at the South Aceh Polytechnic. The research procedure goes through several stages, namely planning, analysis, design, development, testing, implementation, simulation of results, and evaluation. 


\section{The Proposed Method}

\section{Research Method}

In the design of the South Aceh Polytechnic Complaints Information System, the stages carried out are the observation stage, data collection, the implementation stage, the evaluation stage, and the last stage is the implementation result stage.

The research procedure can be seen in the fishbone below:

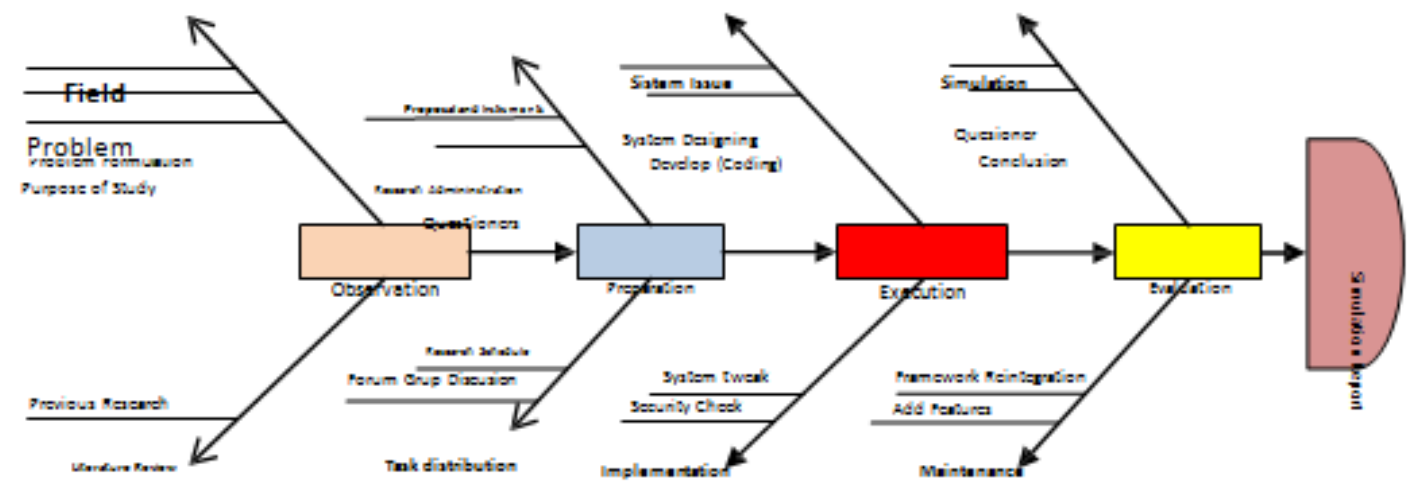

Figure 1. Fishbone Chart of Research

The research stages in this research are:

1. Observation

Observations were made by conducting field studies at the South Aceh Polytechnic to obtain current system data, collect information to identify problems in the running system then formulate problems, and set research objectives. Furthermore, conducting a literature review by looking at previous research to support research carried out. This Stage of Literature Study conducts a collection of journals, websites, articles, theses to find out the theory supporting research and previous studies that have been conducted.

\section{Data Collecting}

This stage collects data that will be used to support the content of this information system such as campus profile data, SPMI data, data for each study program, and other data needed.

\section{Implementation}

At this stage, researchers jointly implement tasks at the preparation stage including system and framework issues to be used, designing and coding and testing the system, finding debugging of the system both security issues and user interface, and then implement it following the SDLC methodology.

4. Evaluation

At this stage, together with the members of the researcher compile, create, and distribute questionnaires regarding the information system understudy to see the weaknesses and the possibility of adding features for later maintenance. Then make conclusions from the questionnaire data on the readiness of the system as a whole.

5. Research

At this stage, the writer makes a report from the simulation results of SIAPA

\section{Method}

In this study, researchers approached the System Development Life Cycle (SDLC) development model so that the process of building this information system was carried out sequentially and wellorganized 


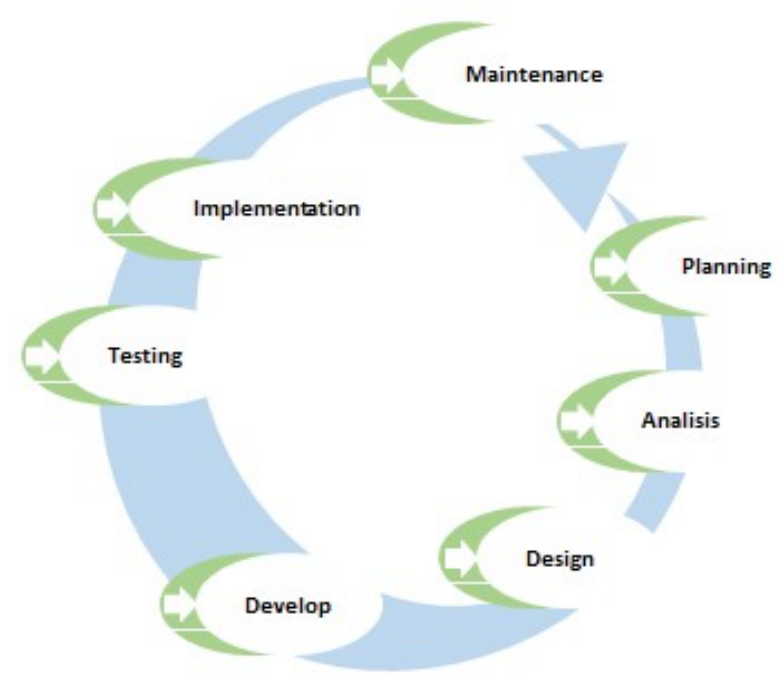

Figure 2.System Development Life Cycle (SDLC)

The SDLC conceptual process model includes:

1. Planning

In this section, the researcher identifies the problem and determines the scope of the research to determine the steps in the process of solving the problem under study, including determining resources, financial budgets, and technical work.

2. Needs Analysis

In this section, the researcher performs a requirements analysis that involves the functional requirements of the end-user system.

3. Designing the system

In this section, researchers design modules, security, architecture, information system interfaces and evaluate the software in both functional and operational aspects.

4. Building Software

In this section, the team worked on building, coding, and improving the overall technical and physical configuration required.

5. Software Testing

This stage tests the system as a whole to answer the expected objectives, this is done to ensure the satisfaction of using the system to end-users and finding errors in the system.

6. Software Implementation

This stage is to release the software ready for use by end-users.

7. Maintenance

At this stage, end users can contribute to improving the system to improve performance and add features. This stage is important to do to evaluate performance and the application of new technology to anticipate cyber security.

In getting maximum results on the SIAPA development case study, the authors focus on using a parallel model approach [7]. This methodology is the development of the waterfall methodology, where the process of designing and implementing the system is carried out sequentially for the entire system and then divided into different sub-activities carried out in parallel. 


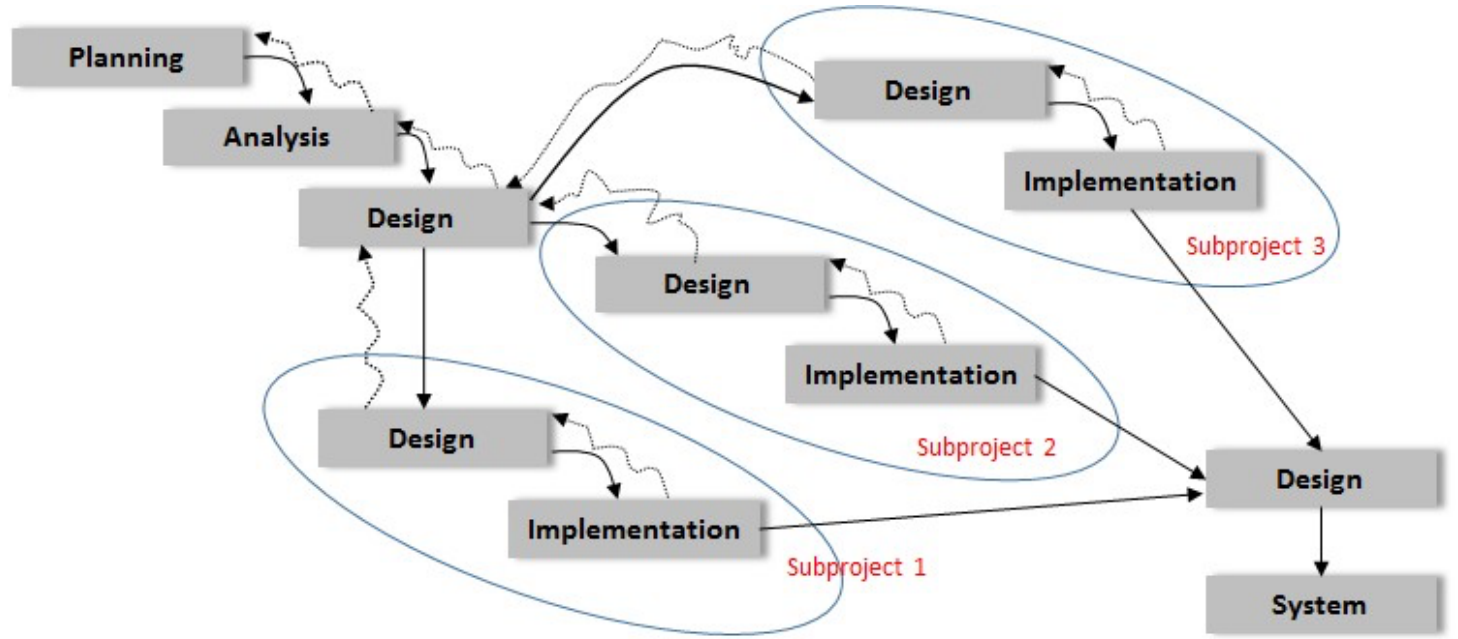

Figure 3.Parallel Model Approach

UML is a set of tools used in abstracting an object-based system or software. Based on research [8], the use of UML is very good in improving the quality of the software produced and the ease of software maintenance in the future, because using UML can identify 11 types of errors in the uses case scenario and 7 errors when modeling the uses case.

\section{Results and Discussion}

Contains the design of the South Aceh Polytechnic Complaints Information System, there are two users, namely admin and user, each user has different access rights according to their respective needs. This system is a website based and support or responsive to appear on mobile phones.

The following is the procedure for the complaint information system for the South Aceh polytechnic:

1. Students or the public who will report must be registered first. If not registered then you are required to register.

2. Students or people who already have an account can report their complaints by logging in first.

3. Open and fill in the complaint form in the form of text and photos to support the complaint.

4. Submit the complaint form.

5. The system will automatically receive the complaint report. Procedure for follow-up complaints reports, namely:

a) Admin verifies the report based on the type of complaint received

b) Admin reports to the implementation team for processing and follows up

c) Admin receives a report from the implementation team of the description of the corrective results of the complaint

d) Admin will update the information in the system that the complaint has been handled properly. 


\section{Design}

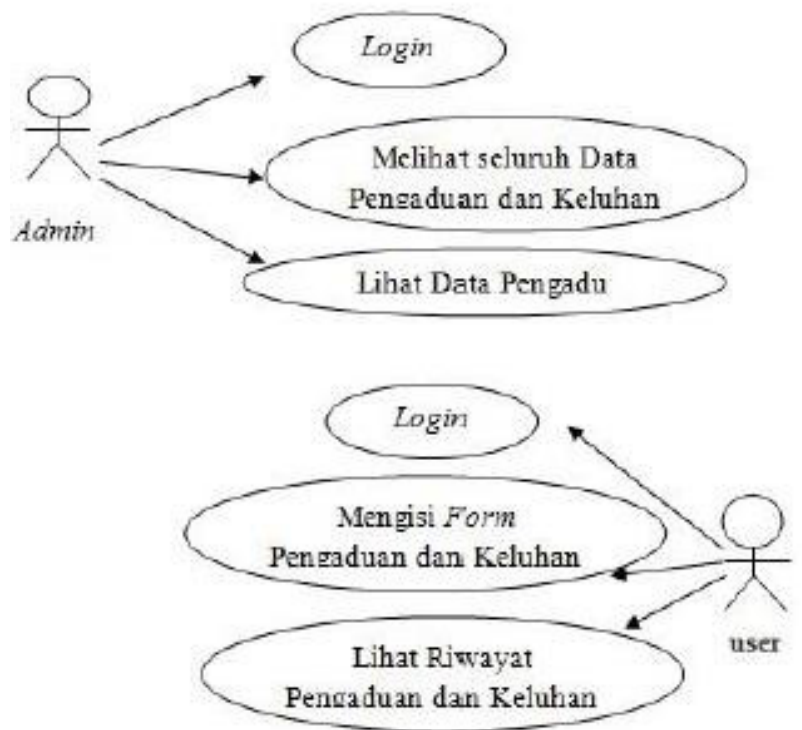

Figure. 4.Use case Complaints Information System

From the use case diagram above, it can be seen that in this system the admin has access rights in the form of login, viewing all complainant data, and can check complaints and complaints that have entered the system. Meanwhile, users only have access rights in the form of logging in, filing complaints, and viewing complaint history.

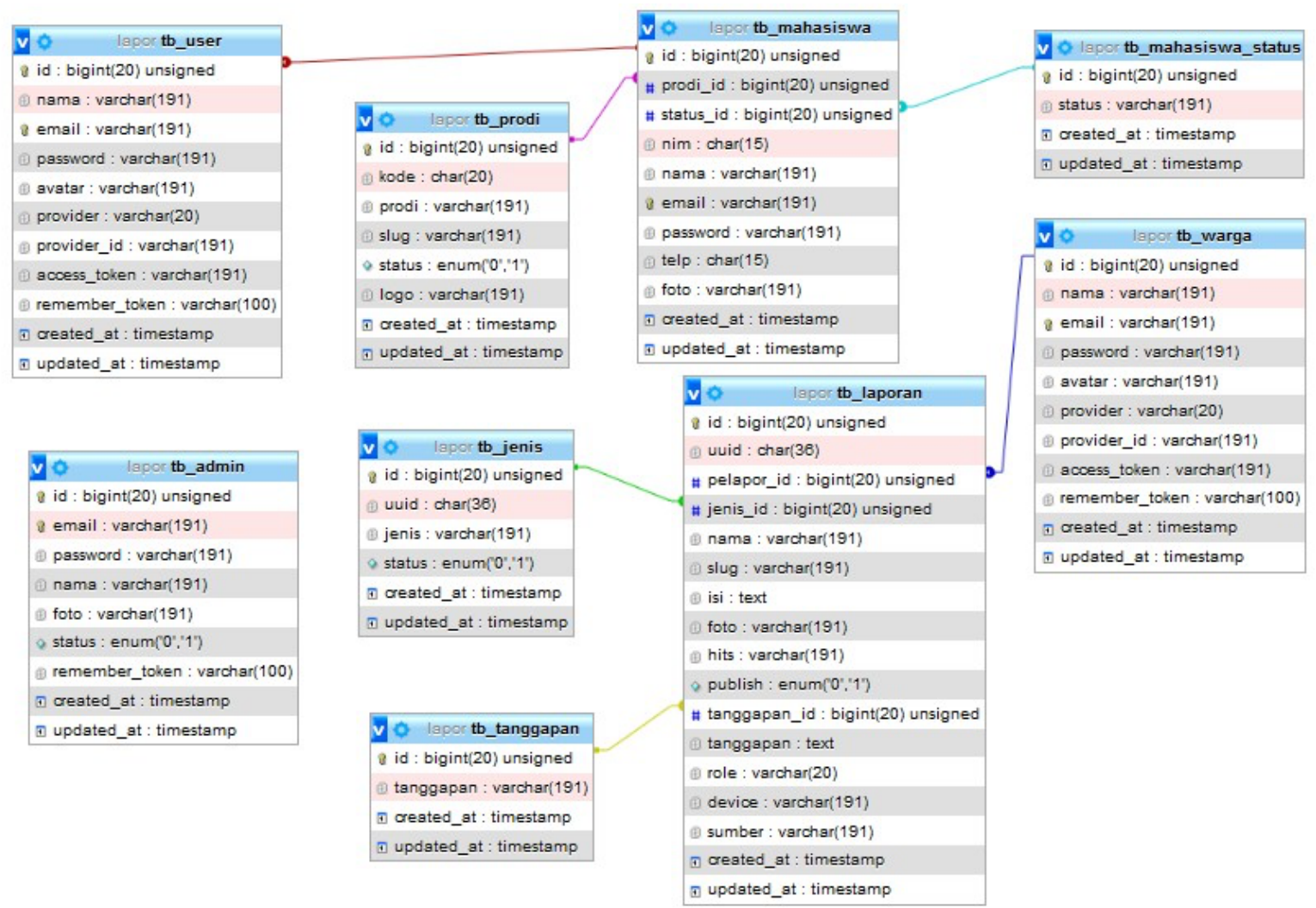

Figure 5. Database Relations Table 
The picture above is a table of database creation using MySQL because the security system is guaranteed and cannot be accessed unless the admin or someone trusted. Collecting data of complaints that enter the system, such as the user's Student ID number (NIM), Email, name, complaint, and time of the complaint.

\section{System Display Interface}

Some of the interfaces of the South Aceh Polytechnic Complaint Information System are as follows:

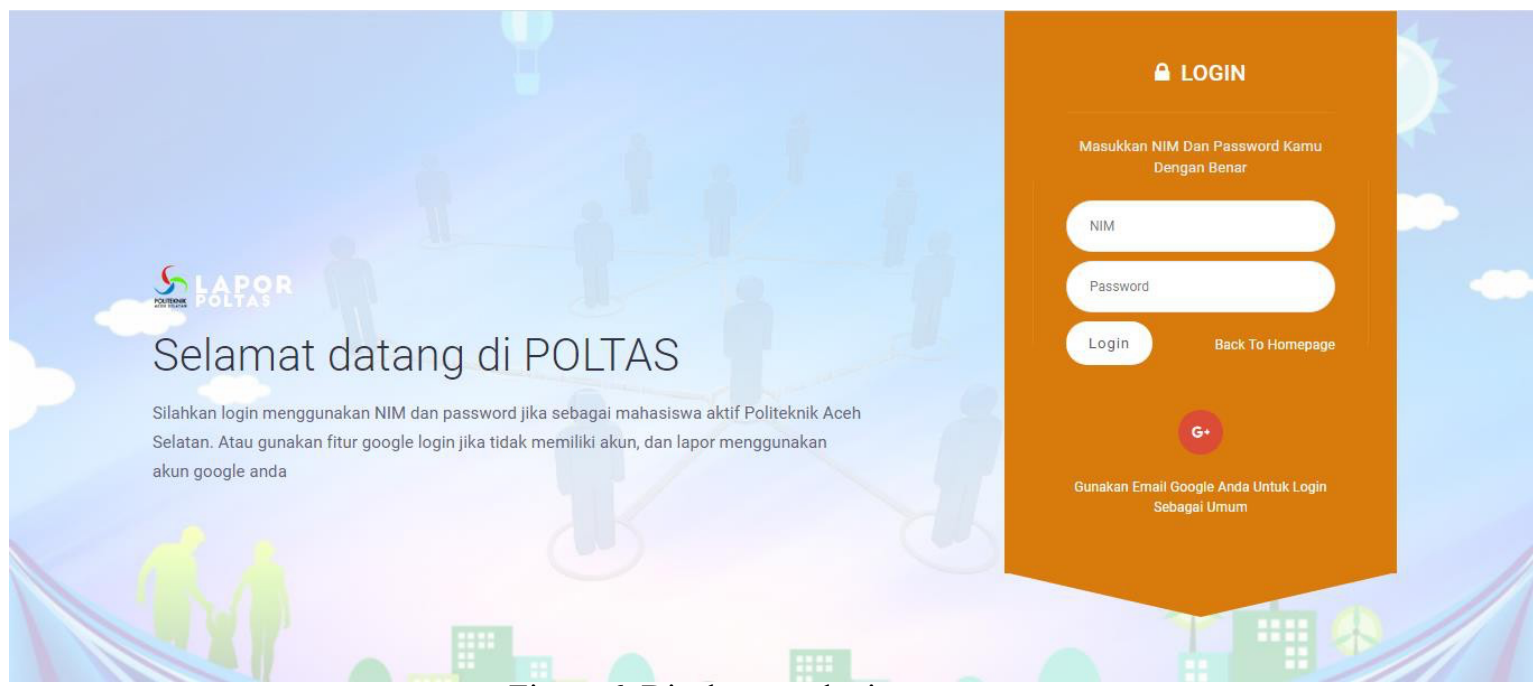

Figure 6. Display user login menu

Users are asked to enter a username and password that has previously registered. To make a complaint, the user is asked to create an account first. After students get an account from the admin to $\log$ in, general users make complaints by using active email to enter the complaint menu.

\section{LAPAOR HOME LOGOUT
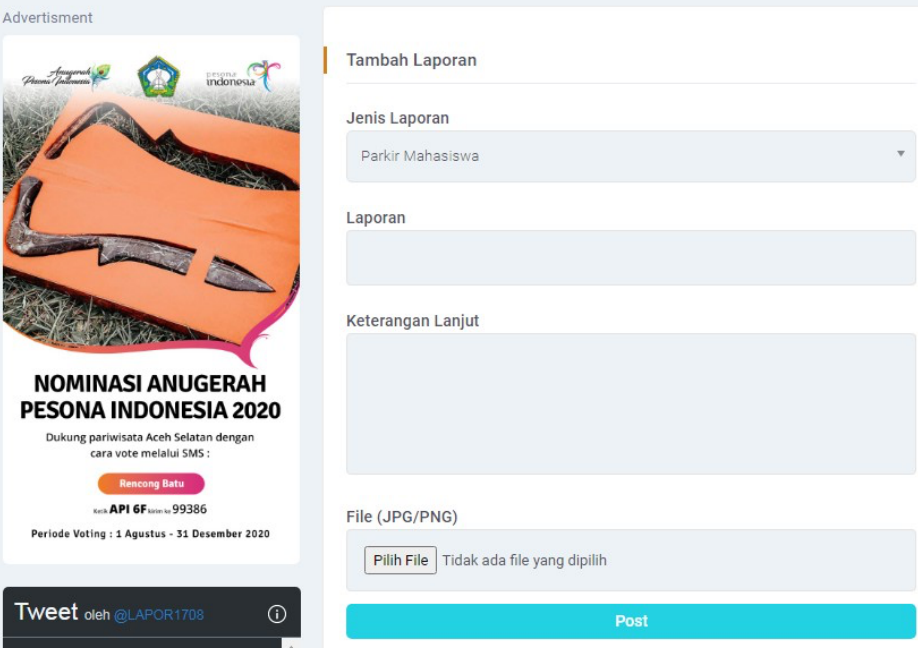

I Tentang Lapor

Umum

Lapor adalah sebuah situs/aplikas

pelayana publik kepada masyarak

kampus dan sekitar agar semua

pelayanan dan ketertiban organisasi

enyelenggara berjalan dengan bak rujuannnya masyarakat umum dàn pengaduan secara internal.

Situs

Shortcuts

으 Semua Laporan

Lill Statistik

Figure 7. Display of the Complaints Menu 
After logging in, the menu above will appear, the user can make a complaint by entering the complaint menu and selecting create a complaint. When making a complaint the user is asked to choose the type of complaint, fill in a description of the complaint, and a photo caption to support it.

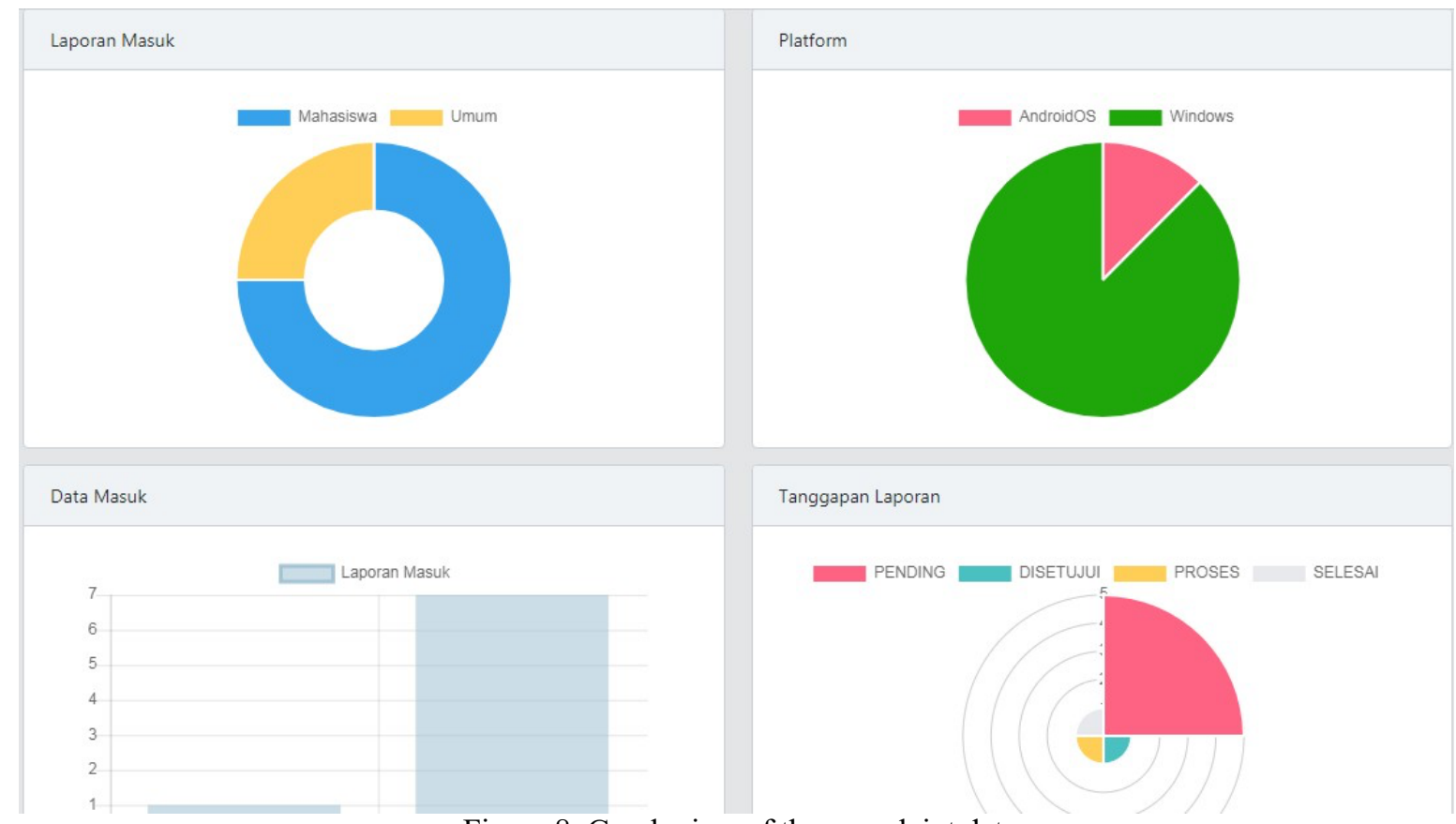

Figure 8. Graph view of the complaint data

In the graph space, the admin can see the graph of incoming complaints from complaints submitted by users or the community, to further improve service to the public.

\section{Conclusion}

With this Complaint Information System, it can make it easier for students and public concerns to report on the academic atmosphere at the South Aceh Polytechnic to maintain consistency as an institution providing vocational higher education, of course, having to innovate towards improving services. For further research, system development can be carried out, based on android or adjusting the needs and policies of users of this system.

\section{References}

[1] K.E.Kendall \& J.E. Kendall, “Analisis dan Perancangan Sistem”, ISBN-978-979-683-800-4, Indeks, 2010

[2] K.C.Laudon\& J. P. Laudon, "Management Information Systems: Managing the Digital Firm", ISBN-13: 978-1-29209400-7, Pearson Education, 2014.

[3] Yakub,’Pengantar Sistem Informasi”, Graha Ilmu, Yogyakarta, 2012.

[4] L.P. Sinambela et all,"Reformasi Pelayanan Publik : Teori, Kebijakan dan Implementasi", ISBN-9795261843, Bumi Aksara, 2014.

[5] Undang-Undang Republik Indonesia Nomer 12 Tahun 2012 Tentang Pendidikan Tinggi.

[6] A. Sulaiman, U.B. Wibowo, "Implementasi Sistem Penjaminan Mutu Internal Sebagai Upaya Meningkatkan Mutu Pendidikan Di Universitas Gadjah Mada", JAMP Vol 4, No. 1, April 2016, Hlm. 17-32.

[7] Ihsan, MA, Liza, TR, Putra, DS, Asmaidi. 2019. Web-Based Learning Media Application. Jurnal Mantik Penusa, 3(2), Desember 2019, e-ISSN 2580-9741. STMIK Penusa. 
[8] T.A. Kurniawan,"Pemodelan Use Case (UML) : Evaluasi Terhadap Beberapa Kesalahan Dalam Praktuk", JTIIK, Vol. 5, No. 1, Maret 2019, Hlm. 77-86, doi : 10.25126/jtiik.201851610, e-ISSN : 2528-6579 